\title{
ULTRATHIN COATINGS OF ELECTRODES AND INFLUENCE OF PHONONS ON AN INCREASE OF CONDUCTIVITY OF LI-ION BATTERIES
}

\author{
D. Lj. Mirjanic ${ }^{1, *}$, J. P. Šetrajčićc ${ }^{1,2}$, S. S. Pelemiš ${ }^{3}$, S. Armakovic ${ }^{2}$ \\ ${ }^{1}$ The Academy of Sciences and Arts of the Republic of Srpska, 78000 Banja Luka, \\ Bana Lazarevića st. 1, Republic of Srpska, B\&H \\ ${ }^{2}$ University of Novi Sad, Faculty of Sciences, Department of Physics, \\ 21000 Novi Sad, Trg Dositeja Obradovića 4, Vojvodina, Serbia \\ ${ }^{3}$ University of Eastern Sarajevo, Faculty of Technology, Karakaj bb, \\ 75400 Zvornik, Republic of Srpska, B\&H
}

\begin{abstract}
This paper present the results of research of behaviour of phonon subsystem in ultrathin coatings that are applied on electrodes in Li-ion batteries and that increase the efficiency of ion transport. Using the method of Green functions it was demonstrated that in ultrathin films, increased mechanical oscillating of crystalline lattice and forming of standing waves occur, while, thermal capacitiveness and conduction of the overall coating decreases. With its increased oscillating, phonons release the ions captured on and within electrodes, and influence the increase of efficiency of ion conductivity.

Keywords: ion conductivity, Li-ion batteries, ultrathin films, phonons, heat capacity.
\end{abstract}

\section{INTRODUCTION}

In this paper we analyze nanostructure materials designed for energy conversion and energy storing. Li-ion batteries could fulfill very highly set goals having in mind their specific energy density [1] in terms of volume (about $300 \mathrm{Wh} / \mathrm{m}^{3}$ ) and weight (about $130 \mathrm{Wh} / \mathrm{kg}$ ). This type of battery has a number of advantages over other battery types, including high capacity, high energy density and operating voltage. Conversely, the power density cannot provide for all the demands of the users. Unfortunately, this bigger surface does not necessarily lead to the expected results. Namely, something that is equally important or even more important is how to design a microstructure of electrode composite available for Li-ions.

In that sense, nanostructure materials play an important role in Li-ion batteries as well. In some cases, nanostructure materials, due to their special morphology, demonstrate unexpected electric-chemical behaviour. Nonetheless, in most cases, when nanostructure materials are used in Li-ion batteries, a decrease of size of up to $10-20 \mathrm{~nm}$ only leads to shorter diffusion length and bigger surface of $\mathrm{Li}$ incorporation in hard matrix. This problem can in principle be solved by use of mezzo-porous and macro- porous active materials with thickness of walls of about 10-20 nm [2]. These materials may solve ion contact between active materials and electrolytes. An equal deal of attention should be paid to achieving good electronic conduction.

On the whole, in order for a Li-ion battery to function, parallel conduction by electrons and ions is necessary, whereas for high-power batteries such conduction is even essential. We will propose a number of nano-architectures of special design, with each given material requiring a special design; such a design cannot be expanded to other types of active materials.

All battery technologies experience kinetic problems related to solid-state diffusion of $\mathrm{Li}$ in electrodes, and in some cases related to the conductivity of electrolytes and the quality of interfaces. In order to improve kinetics, architectures of nanostructure electrodes are usually proposed, although their design is not trivial [2]. They are made in the form of ultrathin film layers, i.e. coatings.

The contact between electrodes should provide mechanical cohesion during the operation of the battery but can also influence the properties of electrodes across the surface modification. Using atomic force microscopy (ACM), surface structures were studied in three binders: polyvinylidene fluoride 
(PVDF), carboxyl methyl cellulose (CMC) and gelatin. An attempt was to find a correlation between the observed structures and determine electro-chemical charge-discharge characteristics. Bonding properties of gelatin, absorbed at various $\mathrm{pH}$ values were measured. Although gelatin has the best properties at $\mathrm{pH}$ of about 9 , the smallest polarization is determined at $\mathrm{pH}$ 12. Both properties are explained based on the observed gelatin structuring as a function of $\mathrm{pH}$ value. Gelatin is also used as surface agent that determines the distribution of nanometer carbon black particles around the micrometer-sized cathodic active particles. It is believed that it is this drop in resistance that significantly improves performances of various cathode materials, such as $\mathrm{LiMn}_{2} \mathrm{O}_{4}$ and $\mathrm{LiCoO}_{2}[3]$.

Lithium-iron-phosphate $\left(\mathrm{LiFePO}_{4}\right)$ is one of the most promising cathode materials for Li-ion batteries due to its high capacity, low price and ecological nature. Improvement of inherent electronic conductivity may be achieved through a number of methods, including the method of carbon coating, ion supervalent doping at the place of $\mathrm{Li}$ and nano-interconnection of electronically conductive materials. By this method, an equally doped material with electronic conductivity as high as $4,8 \cdot 10^{-2} \mathrm{~S} / \mathrm{cm}$ can be obtained. However, as it was expected, improved electronic conductivity does not seem to have improved the performances of $\mathrm{LiFePO}_{4}$. Based on these results, it seems that besides electro-conductivity, ot- her properties of the material such as ion conductivity and phase transformations may also have a strong influence on the efficiency rate [4].

$\mathrm{Li}_{1-\mathrm{x}} \mathrm{CoO}_{2}$ is the most available cathode material commercially. Unfortunately, practical application of $\mathrm{Li}_{1-\mathrm{x}} \mathrm{CoO}_{2}$ is limited by its instability. It fails quickly at potentials higher than 4,2-4,3 V. With the disintegration of cobalt, structural changes and oxidative electrolyte decomposition, dramatic increase in capacities fades at higher potentials. These instabilities can be solved by a coating of $\mathrm{LiCoO}_{2}$ powder with metal oxide coatings from 10 to $100 \mathrm{~nm}$ thick... The examples of metal oxides that were investigated include: $\mathrm{Al}_{2} \mathrm{O}_{3}, \mathrm{ZrO}_{2}, \mathrm{ZnO}, \mathrm{SiO}_{2}$, and $\mathrm{TiO}_{2}$. Metal phosphates, e.g. $\mathrm{AlPO}_{4}$ and metal fluorides e.g. $\mathrm{AlF}_{3}$ have also been analyzed as coatings. Most coating methods are based on techniques such as sol-gel method. Additionally, wet chemical coating methods require high quantities of solution and precursors. Post thermal treatment is necessary even after solgel coating. Conversely, the Atomic Layer Deposition Method (ALD) is a gas-phase method of thin films with the use of sequential, self-limited surface reactions.

ALD requires only a minimum quantity of precursors and ALD coatings are compatible and provide control of atomic thickness. ALD could be a promising alternative manner for coating electrode materials for LIBs [5].
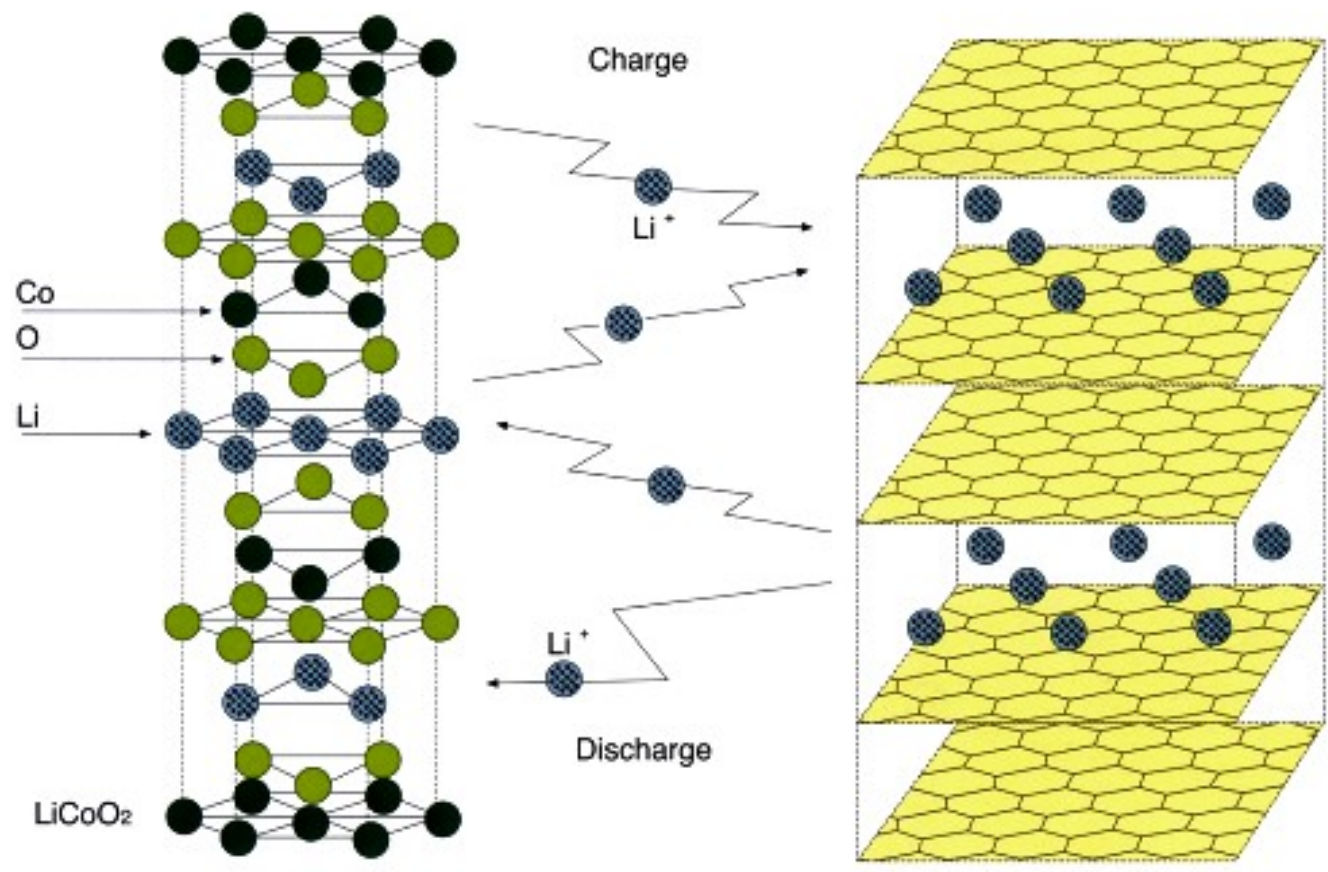

Figure 1. Structure of Li-ion battery 
In the most general case, the efficiency of electrode may be brought in direct connection with the passage of ions. In other words, the bigger passage of ions the bigger efficiency of electrode. A question is readily asked how is it that the increased efficiency of electrodes is a consequence of the presence of coating, because the coating essentially represents an additional „barrier" for the passage of ions. We believe that the answer lies in mechanical properties of coating. Namely, it is possible to draw a full analogy of thin electrode coating with ultrathin films. After drawing the analogy, the only thing that should be examined is a phonon sub-system of ultrathin films, which was done further in the paper, as this is the system responsible for mechanical properties.

\section{ULTRATHIN LAYERS - COATINGS}

Ultrathin films [6-9] are the structures with disrupted symmetry in one direction. Such structures can be analyzed via a single-particle wave function, however such an approach is not self-contained, because statistical formulas have to be "borrowed" in order to calculate the statistical mean values. The only complete method is the method of Green's functions as it gives both dynamic and statistical characteristics of the system.

It should be noted that there are still many unanswered questions considering the application of Green's functions to the structures with disrupted symmetry [10-13]. The reasons for this lie in the fact that in the direction of symmetry disruption, Green's function does not depend on the difference of spatial indices, but on each of them separately. This problem is solved in some papers by examining the Green's function diagonally with space indices in the direction of symmetry disruption, or it is assumed that the Green's function depends on the difference of spatial coordinates in the direction of symmetry disruption, and then the corrections are made in its Fourier-image, which is impulse-dependant, based on the fact that the impulse component is not sustainable in the direction of symmetry.

None of the mentioned approaches reproduce the basic characteristic of the system with disrupted symmetry, or only reproduce it partly; this characteristic is the dependence of physical characteristics of the structure with disrupted symmetry upon the spatial coordinates. The purpose of this paper is to formulate the correct methodology of computation of Green's functions [14-15] in the structures with disrupted symmetry and to apply it to the analysis of mechanical oscillations in ultrathin film.

\section{GREEN'S FUNCTIONS FOR SMALL PHONON MOVEMENTS}

Hamiltonian of mechanical oscillations in the film /taken/ in the approximation of closest neighbours while neglecting torsion effects has the following form:

$$
\begin{aligned}
H & =\frac{1}{2 M} \sum_{\vec{n}} p_{\vec{n}}^{2}+\frac{C}{2} \sum_{\vec{n}}\left[\left(u_{\vec{n}}-u_{\vec{n}-\vec{a}_{x}}\right)^{2}+\right. \\
& \left.+\left(u_{\vec{n}}-u_{\vec{n}-\vec{a}_{y}}\right)^{2}+\left(u_{\vec{n}}-u_{\vec{n}-\vec{a}_{z}}\right)^{2}\right],
\end{aligned}
$$

whereby $u$ - are moves, $p$ - pulses, $M$ - molecule masses and $C-$ Hooke's spring constants.

Green's function of double movement type is given with:

$$
\begin{gathered}
\Psi_{\vec{n}, \vec{m}}(t) \equiv \Psi_{n_{x}, n_{y}, n_{z} ; m_{x}, m_{y}, m_{z}}(t) \equiv \\
\equiv<<u_{\vec{n}}(t) \mid u_{\vec{m}}(0)>>=\theta(t)<\left[u_{\vec{n}}(t), u_{\vec{m}}(0)\right]>
\end{gathered},
$$

and of double impulse type:

$$
\begin{aligned}
& \Phi_{\vec{n}, \vec{m}}(t) \equiv \Phi_{n_{x}, n_{y}, n_{z} ; m_{x}, m_{y}, m_{z}}(t) \equiv \\
\equiv< & <p_{\vec{n}}(t) \mid p_{\vec{m}}(0)>>=\theta(t)<\left[p_{\vec{n}}(t), p_{\vec{m}}(0)\right]>
\end{aligned} .
$$

When solving the equations for these Green functions, it was assumed that the film in $x$ and $y$ directions is translation-invariant. In the direction of disruption of symmetry, the border conditions are the following

$$
\begin{aligned}
& u\left(n_{z}=-1\right)=u\left(n_{z}=N_{z}-1\right)=0 ; \\
& p\left(n_{z}=-1\right)=p\left(n_{z}=N_{z}-1\right)=0 .
\end{aligned}
$$

Due to the border conditions, the equations for determining $\Psi$ and $\Phi$ are disintegrated into a system of three equations. Therefore, the components of functions $\Psi$ and $\Phi$, dependent on the index of layer $n_{z}$, had to be developed by standing waves of form $\sin \left(N_{z}+2\right) \varphi_{\mu}$, whereby parameter $\varphi_{\mu}$ was given with:

$$
\varphi_{\mu}=\frac{\pi \mu}{N_{z}+2} ; \quad \mu=1,2, \ldots, N_{z}+1
$$

It is a very important fact that in the formula (2.5) number $\mu$ could not assume the value 0 and $N_{z}+2$, because Green's functions $\Psi$ and $\Phi$ would then equal to zero.

For Kronecker symbol in $z$ direction, representation of the standing waves was used:

$$
\delta_{n_{z}, m_{z}}=\frac{2}{N_{z}+2} \sum_{\mu=1}^{N_{z}+1} \sin \left(n_{z}+1\right) \frac{\pi \mu}{N_{z}+2} \cdot \sin \left(m_{z}+1\right) \frac{\pi \mu}{N_{z}+2} .
$$

By the described method, the Green's functions $\Psi$ and $\Phi$ were found, and their pole in $E$ plane gave the following value for phonon dispersion law in film: 


$$
\begin{gathered}
E=2 \hbar \Omega \sqrt{\sin ^{2} \frac{a_{x} k_{x}}{2}+\sin ^{2} \frac{a_{y} k_{y}}{2}+\sin ^{2} \frac{\pi \mu}{2\left(N_{z}+2\right)}} \\
\Omega=\sqrt{\frac{C}{M}} ; \quad \mu=1,2, \ldots, N_{z}+1 .
\end{gathered}
$$

After this, spectral intensiveness of functions $\Psi$ and $\Phi$ were determined based on a usual procedure, and through them appropriate correlation functions

$$
<u_{m_{x}, m_{y}, m_{z}}(0) u_{n_{x}, n_{y}, n_{z}}(t)>\text { and }<p_{m_{x}, m_{y}, m_{z}}(0) p_{n_{x}, n_{y}, n_{z}}(t)>\text {. }
$$

Mean values of movement square and impulse square were found with these correlation functions and they were given with the formulae:

$$
\begin{gathered}
<p_{\vec{n}}^{2}>=\frac{\hbar M}{N_{x} N_{y}\left(N_{z}+2\right)} \sum_{k_{x}, k_{y}} \sum_{\mu=1}^{N_{z}+1} \omega_{k_{x}, k_{y}, \mu} . \\
\cdot \sin ^{2}\left(n_{z}+1\right) \frac{\pi \mu}{N_{z}+2} \operatorname{coth} \frac{\hbar \omega_{k_{x}, k_{y}, \mu}}{2 \Theta} \\
<u_{\vec{n}}^{2}>=\frac{\hbar}{M} \frac{1}{N_{x} N_{y}} \frac{1}{N_{z}+2} \sum_{k_{x}, k_{y}} \sum_{\mu=1}^{N_{z}+1} \frac{1}{\omega_{k_{x}, k_{y}, \mu}}, \\
\cdot \sin ^{2}\left(n_{z}+1\right) \frac{\pi \mu}{N_{z}+2} \operatorname{coth} \frac{\hbar \omega_{k_{x}, k_{y}, \mu}}{2 \Theta}
\end{gathered}
$$

It is evident from the results obtained that unlike the ideal structure, the mean squares of movement and impulse depend on space coordinate $n_{z}$.

\section{RESULT ANALYSIS}

Based on the expression for phonon energy (2.7), minimum phonon energy is obtained for $k_{x}=k_{y}=0$ and $\mu=1$. This minimum value amounts to:

$$
E_{\min }=2 \hbar \Omega \sin ^{2} \frac{\pi}{2\left(N_{z}+2\right)}
$$

As it can be seen, the minimum phonon energy in the film is not equal to zero like in the ideal structure, and for a three-layer film $\left(N_{z}=2\right)$ it amounts to $2 \hbar \Omega \sin ^{2} \frac{\pi}{8}$ which, for Debye's temperatures of order $200 \mathrm{~K}$ gives the energy threshold for phonons which is of order $100 k_{B}$. This fact is very significant because it practically means that up to the temperature of $100 \mathrm{~K}$ the film behaves like an ideal structure on absolute zero, that is to say, it does not show any resistance to movement of electrons. Therefore, ultrathin metal films can be expected to be high-temperature super-conductors.

With the mean square of movement in the film, the following film density was determined

$$
\rho=\frac{m}{a^{3}\left(1-3 \frac{<u_{\vec{n}}^{2}>}{a^{2}}\right)}
$$

because $<u_{\vec{n}}^{2}>$ depends on $n_{z}$, film density changes from layer to layer, and its values for ultrathin film are the highest in border layers, and lowest in the middle layer. Due to this, density of the film as a whole cannot be determined, therefore we introduced a convention that arithmetic mean of densities by layers is treated as density of the film as a whole.

By way of correlation functions, internal energy of the film was determined as a sum of mean values of Hamiltonian of film by layers [16-18]. It was possible to determine specific heat of the film only for film layers, therefore, according to the convention, the arithmetic mean of specific heats by layers was treated as specific heat of the entire film. By comparing specific heat of the film defined in such a way, with the specific heat of ideal structure, it was determined that at low temperatures specific film heat is by several orders of magnitude lower than the specific heat of ideal structure, that in the interval $(80,97) \mathrm{K}$ it is somewhat higher than the heat of the ideal structure, and that at temperatures higher than $97 \mathrm{~K}$ it becomes lower again.

The film heat conductivity, given with the following formula, has a similar behaviour:

$\lambda=D \cdot C_{V} \cdot \rho$,

whereby $D$ is a diffusion ration. With regards to the ideal structure, the heat transfer ratio behaves similarly to specific heat, which means that at low temperatures it is by a few orders of magnitude lower than the heat ratio of the ideal structure, that in the interval of temperatures $(76,5-101,5) \mathrm{K}$ is insignificantly higher and that at temperatures higher than $101,5 \mathrm{~K}$ it is lower again than the heat conductivity ratio of ideal structure.

In figures 2 and 3 dependences of specific heat and heat transfer ratio on temperature, respectively for film and ideal structure, are presented.

A general conclusion derived from the comparison of specific heat and heat transfer ratio for film and the ideal structure is that the film has high thermal-insulation properties.

We will finally determine diffusion tensor of phonons which is, based on [19], determined by the formula

$$
D_{\vec{n} \vec{m}}=\left|\lim _{\varepsilon \rightarrow 0} \int_{0}^{\infty} d t e^{-\varepsilon t} \frac{<p_{\vec{m}}(0) p_{\vec{n}}(t)>}{M^{2}}\right| .
$$

By using the correlation function derived from Green's function of double impulse type we find that the diffusion tensor of phonon is diagonal and that all of its diagonal elements are the same. The formula obtained for the diffusion tensor is as follows:

$D_{n_{x}, n_{y}, n_{z} ; m_{x}, m_{y}, m_{z}}=\frac{\hbar}{2 M} \delta_{n_{x}, m_{x}} \delta_{n_{y}, m_{y}} \delta_{n_{z}, m_{z}}$. 
As it can be seen, the value of diagonal element in (3.5) $D=\frac{\hbar}{2 M}$, which represents the diffusion ration,

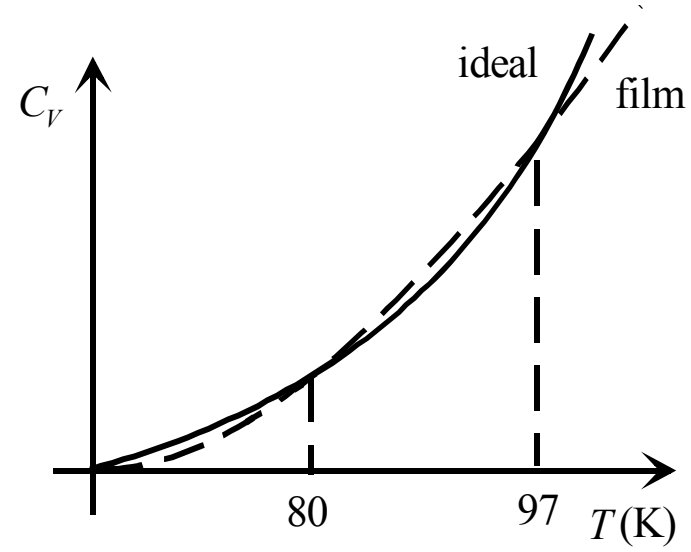

Figure 2. Specific heat

In phonon sub-system of ultrathin films, responsible for mechanical properties, the increased oscillations and forming of stationary waves occur, whereas thermal conductivity decreases. Due to an increase in phonon influence, their positive effect on the size of ion-phonon interaction can be expected, having in mind that a considerable part of thermal energy is spent for this increase. Based on that we can conclude that a response with regards to the mechanism of higher efficiency of ion transport could include positive influence of vibrations of crystal lattice of electrode coatings. Those vibrations have a sort of "reanimating" or "reviving" effect on ions, thus creating conditions for their more frequent and faster transfer. On the other hand, with their increased oscillating, phonons release the ions "captured" within and on electrodes, which, without the presence of coatings could never again be able to take part in transfer of electrical charge and energy between electrodes within Li-ion batteries. In that way, this system: electrodes with ultrathin coatings - has an effect to increase the efficacy of Li-ion conduction.

It is noteworthy that the thinner the thickness of coating, the bigger the influence of phonons!

\section{CONCLUSION}

The paper outlines the results of research of behaviour of phonon sub-system in ultrathin coatings that are laid on electrodes in Li-ion batteries and increase the efficacy of ion transport. It has been demonstrated that increased mechanical oscillating of crystal lattice occurs in ultrathin films, as well as the forming of standing waves, whereas the thermal capacitivity and conduction of the overall coating decreases. With their increased oscillating phonons does not depend on temperature or on coordinates.

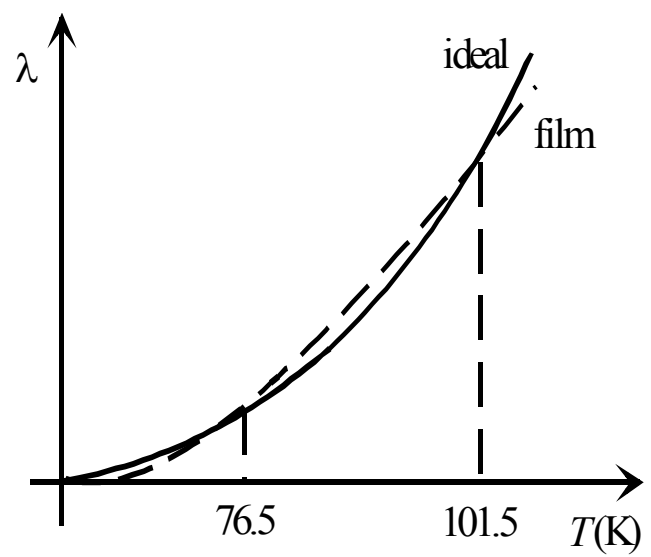

Figure 3. Heat transfer ratio

release the ions "captured" in and on electrodes, which ions, without the presence of coatings would not be able any more to take part in transfer of charge and energy between the electrodes within Li-ion batteries. In this way, this system: electrodes with ultrathin coatings - influences an increase in efficiency of Li-ion conduction.

\section{ACKNOWLEDGMENT}

Studies the results of which were presented in this paper were financially supported by the Republic of Srpska and the Republic of Serbia Ministries of Science.

\section{REFERENCES}

[1] J. M. Tarascon, M. Armand, Issues and challenges facing rechargeable lithium batteries, Nature 414 (2001) 359-367.

[2] P. L. Taberna, S. Mitra, P. Poizot, P. Simon \& J. M. Tarascon, High rate capabilities $\mathrm{Fe}_{3} \mathrm{O}_{4}$-based $\mathrm{Cu}$ nano-architectured electrodes for lithium-ion battery applications, Nature Materials 5 (2006) 567-573.

[3] S. Pejovnik, R. Dominko, M. Bele, M. Gaberscek and J. Jamnik, Electrochemical binding and wiring in battery materials, Journal of Power Sources, 184-2 (2008) 593-597.

[4] J. Hong, Ch. Wang, U. Kasavajjula, Kinetic behavior of LiFeMgPO4 cathode material for Li-ion batteries, Journal of Power Sources 162 (2006) 1289-1296.

[5] Y. S. Jung, A. S. Cavanagh, A. C. Dillon, M. D. Groner, S. M. George, and Se-Hee Leea, En- 
hanced Stability of $\mathrm{LiCoO}_{2}$ Cathodes in Lithium-Ion Batteries Using Surface Modification by Atomic Layer Deposition, Journal of The Electrochemical Society, 157-1 (2010) A75-A81.

[6] D. Popov, S. K. Jaćimovski, B. S. Tošić, J. P. Šetrajčić, Kinetics of thin films mechanical oscillations, Physica A 317 (2003) 129-139.

[7] B. S. Tošić, J. P. Šetrajčić, D. Lj. Mirjanić, Z. V. Bundalo, Low-Temperature Properties of Thin Films, Physica A, 184 (1992) 354-366.

[8] S. G. Davison and M. Steslicka, Basic Theory of Surface States, Clarendon, Oxford (1996).

[9] M. Prutton, Introduction to Surface Physics, Clarendon, Oxfod (1995).

[10] M. Tkach, V. Holovatsky, O. Voitsekhivska, Electron and hole quasistationary states in opened cylindrical quantum wire, Physica E, 11 (2001) 17-26.

[11] V. M. Golovach, G. G. Zegrya, A. M. Makhanets, I. V. Pronishin, N. V. Tkach, Electron and hole spectra in a superlattice of cylindrical quantum wires, Semiconductors, vol.33/5 (1999) 564-568.
[12] J. M. Wesselinowa, On the theory of thin ferroelectric films, Phys.Stat.Sol. (b), vol. 223 (2001) 737.

[13] J. M. Wesselinowa, Electric field dependence of phase transitions in ferroelectric thin films, Phys.Stat.Sol. (b), 229 (2002) 1329.

\section{vi Sad (1978).}

[14] B. S. Tošić, Statisticka fizika, PMF, No-

[15] S. Doniach, E. H. Sondheimer, Green's Functions for Solid State Physicists, Imperial College Press, London (1999).

[16] C. Kittel, Introduction to Solid State Physics, Wiley, New York (1986).

[17] H. Ibach, H. Lüth, Solid-State Physis, An Introduction to Principles of Material Science $3^{\text {rd }}$ edition, Springer, Berlin / Heidelberg / New York (2003).

[18] G. Strobl, Condensed Matter Physics, Crystals, Liquid Crystals and Polymers, Springer, Berlin/Heidelberg/New York (2004).

[19] V. M. Agranovich and M. D. Galanin, Migration of Electron Energy Excitations in Condensed Matter, Nauka, Moscow (1978).

\title{
УЛТРАТАНКЕ ПРЕВЛАКЕ ЕЛЕКТРОДА И ФОНОНСКИ УТИЦАЈ НА ПОВЕЋАҢЕ ПРОВОДНОСТИ КОД Lі-ЈОНСКИХ БАТЕРИЈА
}

\begin{abstract}
Сажетак: У раду су представљени резултати истраживања понашања фононског подсистема у ултратанким превлакама какве се наносе на електроде у Li-joнским батеријама и повећавају ефикасност јонског транспорта. Методом Гринових функција показано је да у ултратанким филмовима долази до појаве појачаног механичког осциловања кристалне решетке и формирања стојећих таласа, а смањења термичке капацитивности и проводљивости цијеле превлаке. Својим појачаним осциловањем фонони ослобађају у и на електродама заробљене јоне и тако утичу на повећање ефикасности јонског провођења.

Кључне ријечи: јонска проводност, Li-jонске батерије, ултратанки филмови, фонони, топлотна капацитивност.
\end{abstract}

